\title{
Globalscale species distributions predict temperaturerelated changes in species composition of rocky shore communities in Britain
}

\section{Burrows, MT}

http://hdl.handle.net/10026.1/15415

10.1111/gcb.14968

Global Change Biology

Wiley

All content in PEARL is protected by copyright law. Author manuscripts are made available in accordance with publisher policies. Please cite only the published version using the details provided on the item record or document. In the absence of an open licence (e.g. Creative Commons), permissions for further reuse of content should be sought from the publisher or author. 
DR. MICHAEL T BURROWS (Orcid ID : 0000-0003-4620-5899)

DR. NOVA MIESZKOWSKA (Orcid ID : 0000-0002-9570-7759)

Article type : Primary Research Articles

Title: Global-scale species distributions predict temperature-related changes in species composition of rocky shore communities in Britain

Running title: Climate-related change in intertidal communities

Michael T. Burrows ${ }^{1}$, Stephen J. Hawkins ${ }^{2,3,6}$, J. Jon Moore ${ }^{4}$, Leoni Adams ${ }^{2,3}$, Heather Sugden $^{5}$, Louise Firth ${ }^{6}$, Nova Mieszkowska ${ }^{3,7}$

1. Scottish Association for Marine Science, Oban, PA37 1QA, UK.

2. School of Ocean and Earth Science, University of Southampton, National Oceanography Centre, SO14 3ZH, UK

3. Marine Biological Association, Plymouth, PL1 2PB, UK.

4. Aquatic Survey and Monitoring Ltd., Cosheston, Pembrokeshire, SA72 4UN, UK

5. The Dove Marine Laboratory, School of Natural and Evironmental Sciences, Newcastle University, Cullercoats, North Shields, NE30 4PZ, UK

6. School of Biological and Marine Sciences, University of Plymouth, Plymouth, PL4 8AA, UK

7. School of Environmental Sciences, University of Liverpool, Liverpool, L69 3BX, UK

This article has been accepted for publication and undergone full peer review but has not been through the copyediting, typesetting, pagination and proofreading process, which may lead to differences between this version and the Version of Record. Please cite this article as doi: 10.1111/GCB.14968

This article is protected by copyright. All rights reserved 


\title{
Correspondence
}

Michael T. Burrows, Scottish Association for Marine Science, Scottish Marine Institute, Oban, PA37 1QA, UK. Email: mtb@sams.ac.uk

\section{Funding information}

UK Natural Environment Research Council Grant/Award Number: NE/J024082/1. UK MarClim Consortium: Scottish Natural Heritage, Marine Scotland Science, Joint Nature Conservation Committee, Natural England, Natural Resources Wales, Isle of Man Government. Cyfoeth Naturiol Cymru, Crown Estate, Defra, Marine Scotland, Environment Agency, UK Climate Impacts Programme, States of Jersey. Sullom Voe Association Limited.

KEYWORDS: climate change, community composition, thermophilization

\begin{abstract}
Changes in rocky shore community composition as responses to climatic fluctuations and anthropogenic warming can be shown by changes in average species thermal affinities. In this study we derived thermal affinities for European Atlantic rocky intertidal species by matching their known distributions to patterns in average annual sea surface temperature. Average thermal affinities (the Community Temperature Index, CTI) tracked patterns in sea surface temperature from Portugal to Norway, but CTI for communities of macroalgae and plant species changed less than those composed of animal species. This reduced response was in line with the expectation that communities with a smaller range of thermal affinities among species would change less in composition along thermal gradients and over time. Local-scale patterns in CTI over wave exposure gradients suggested that canopy macroalgae allow species with ranges centred in cooler than local temperatures ("cold-affinity") to persist in otherwise too-warm conditions. In annual surveys of rocky shores, communities of animal species in Shetland showed a shift in dominance towards warm-affinity species ("thermophilization") with local warming from 1980 to 2018 but the community of plant and macroalgal species did not. From 2002 to 2018, communities in southwest Britain showed the reverse trend in CTI: declining average thermal affinities over a period of modest temperature decline. Despite the cooling, trends in species abundance were in line with the general
\end{abstract}


mechanism of direction and magnitude of long-term trends depending on the difference between species thermal affinities and local temperatures. Cold-affinity species increased during cooling and warm-affinity ones decreased. The consistency of responses across different communities and with general expectations based on species thermal characteristics suggests strong predictive accuracy of responses of community composition to anthropogenic warming.

\section{Introduction}

Persistent warming is a well-established reality for the oceans, and until recently, there had been little systematic effort to synthesise the widely reported effects on biodiversity (Poloczanska et al., 2013; Sorte, Williams, \& Carlton, 2010). Yet abundance and distributions and their changes for species living on intertidal rocky shores have long been presented as examples of responses to environmental gradients (Hutchins, 1947) and change in the oceans (A.J. Southward \& D.J. Crisp, 1954), with those in northwest Europe having been particularly well studied in relation to temperature (Crisp \& Fischer-Piette, 1959; Crisp \& Southward, 1958; Fischer-Piette, 1936; A. J. Southward \& D. J. Crisp, 1954; A.J. Southward \& D.J. Crisp, 1954). Increases in abundance of warm-affinity species and declines in coldaffinity ones (N. Mieszkowska, Burrows, Pannacciulli, \& Hawkins, 2014; A.J. Southward, 1991; A. J. Southward, Hawkins, \& Burrows, 1995), poleward advances of species at cold range edges (e.g. Hawkins et al., 2009; Herbert, Hawkins, Sheader, \& Southward, 2003; N. Mieszkowska, Kendall, et al., 2006) and retreats of species at warm boundaries (Jones, Southward, \& Wethey, 2012) relative to limits in 1950s and 1960s have all been observed with warming. While species interactions such as grazing are involved in controlling abundance change across latitudinal gradients (Coleman et al., 2006; Jenkins et al., 2005), thermal tolerances closely follow latitudinal ranges of many species (Breeman, 1988; Sunday, Bates, \& Dulvy, 2012), implying direct links between survival and temperature. This close link has led to simple predictions of range changes based on shifts in isotherms (Burrows et al., 2011; Loarie et al., 2009). Difficulties in tracking range edges over time (Bates et al., 2015; Tingley \& Beissinger, 2009), however, make relating range shifts to isotherm shifts impractical as a way of measuring responses to climate.

This article is protected by copyright. All rights reserved 
More tractably, linking changes in abundance and frequency of occurrence of species to their thermal affinity allows assessment of the effects of warming for species assemblages at defined locations. When changes have been observed over a period of warming, coldaffinity species (boreal species in northwest Europe) typically decline and warm-affinity species increase, as seen for bottom-living fishes of the European continental shelf (Genner et al., 2004; Simpson et al., 2011) and Mediterranean (Givan, Edelist, Sonin, \& Belmaker, 2018). The prevalence of the pattern of changes in relation to thermal affinities of species suggests that "cold-affinity species decline and warm-affinity species increase with warming" may serve as a general rule, with the widely observed changes termed "thermophilization" in terrestrial vegetation (De Frenne et al., 2013). Thermophilization can be measured using the weighted average of thermal affinities of species that make up a community, the Community Temperature Index (CTI). CTI change reflects changing species dominance and composition when weighted by abundance or frequency of occurrence, and turnover when weighting by presence alone. CTI has been widely used to track changes in natural communities (Vincent Devictor, Julliard, Couvet, \& Jiguet, 2008), and exploited species (Cheung, Watson, \& Pauly, 2013), The relative contribution of each species to compositional change is attributable to their themal affinity, with increasing CTI in some places associated with declines in coldaffinity species (birds in France, Tayleur et al., 2016) and increases in warm-affinity ones in others (birds in North America Prince \& Zuckerberg, 2015). The difference between local temperature change and composition change expressed by CTI has been interpreted as climate 'debt' (V. Devictor et al., 2012), the catching-up needed for community composition to track temperature changes perfectly. But smaller shifts in average thermal affinity may result from the collective responses of highly eurythermal species, or where many species share similar affinities (Burrows et al., 2019; Flanagan, Jensen, Morley, \& Pinsky, 2019).

Further measures based on species thermal affinities show promise for projecting how communities might respond to climate. The difference between CTI and local temperature, termed the thermal bias, suggests local extinctions in relation to climate warming (StuartSmith, Edgar, Barrett, Kininmonth, \& Bates, 2015) where this measure is negative. Species in such places tend to have distributions centred in colder regions than the location considered, and may face a greater threat of local extinction since they are more likely to be approaching their upper thermal limits. The range of thermal affinities, expressed as community thermal diversity (the abundance-weighted standard deviation of STIs, hereafter CTDiv), can predict the likely responsiveness of the CTI to temperature change (Burrows et al., 2019). Communities composed of species with similar thermal affinities are likely to change less in 
composition with warming or cooling than those communities composed of diverse thermal types. Similarly, communities made up of narrow-ranged species may be more responsive to temperature change with a more rapid species turnover (higher beta diversity) and faster rate of CTI change relative to temperature change. These latter effects are suggested by simulations based on species abundance-temperature curves and seen in CTI changes in bottom-trawl and plankton datasets over the last 30 years (Burrows et al., 2019).

Patterns in average species thermal affinity across smaller scales can reveal thermal influences on community composition among nearby sites and the effects of thermal microclimates within sites. Communities protected from thermal extremes, such as those under forest canopies, on shaded slopes or on complex intertidal surfaces (Firth et al., 2016), may be buffered from the effects of climate change. In UK grassland, CTI change is greater in exposed microclimates (Maclean, Hopkins, Bennie, Lawson, \& Wilson, 2015), a habitat potentially equivalent to open rock on wave-exposed shores. Wave-sheltered rocky shores in temperate regions tend to be dominated by large canopy-forming macroalgae (Burrows, Harvey, \& Robb, 2008; Lewis, 1964) such that temperatures under algal canopies are cooler than on nearby rock on sunny summer days (Moore, Hawkins, \& Thompson, 2007), potentially offering climatic refuges for high-temperature-sensitive species. Such complex patterns of thermal habitat variation in the rocky intertidal may mask the effects of latitudinal gradients in air and sea temperature on species distributions along continental coastlines (Helmuth et al., 2006), with often greater differences among temperatures within sites than across whole-continent latitudinal gradients, and latitudinal patterns of some metrics counter to simple expectations of poleward decreases (Seabra, Wethey, Santos, \& Lima, 2015).

In this study, we examined evidence for temperature as a driver of community composition in spatial patterns in CTI in rocky intertidal communities using a large dataset of European surveys, and contrast responses of communities of primary producers with communities comprised of higher trophic level species. We aimed to assess the effects of wave exposure on community thermal affinity, thought to be due to local modification of thermal habitat through intertidal canopy-forming algae (Pocklington et al., 2018), through associated changes in composition of higher trophic level (animal) communities. While some survey sites were not visited every year since 2002, annually repeated surveys at sites across SW Britain over two decades (17 years, 2002-2018) and over four decades (41 years, 19762018) for a set of sites around an oil terminal in Shetland allowed responses of communities to changes in temperature to be measured using the CTI approach. Trends in CTI were compared with the magnitude and direction of temperature change, and were predicted to be 
modified positively by the diversity of thermal affinities among the constituent species (CTDiv), negatively by the average thermal range of species (CTR), and with more declines in species abundance in areas of negative thermal bias.

\section{Materials and Methods}

Thermal affinities of rocky shore species were obtained by extracting average coastal sea surface temperatures across the geographical range of each species. Each Species Temperature Index (STI) was derived as the median within-range sea temperature, with Species Thermal Range (STR), the spread of temperatures occupied (Table S1), as the difference between $10^{\text {th }}$ and $90^{\text {th }}$ percentile within-range temperatures. Species distribution ranges were derived from literature reports of species presence (Table S2). Geographical ranges were drawn as polygon shapefiles (ESRI format) encompassing coasts inside the known range of each species. Sea temperatures were taken from 1982 to 2011 averages in the NOAA Optimal Interpolated Sea Surface Temperature dataset (OISSTv2 HR, Reynolds et al., 2007), using only $0.25^{\circ}$ latitude/longitude cells adjacent to the coastline. Quantiles of withinrange temperatures giving STI and STR values were area-weighted by grid cell area using the cosine of latitude. Three metrics of community thermal affinity for communities in surveys were derived from STIs and species abundance: Community Temperature Index (CTI), the abundance-weighted mean of all STIs; Community Thermal Diversity (CTDiv, Burrows et al 2019), the abundance-weighted standard deviation of all STIs; and Community Thermal Range (CTR, Burrows et al., 2019), the abundance-weighted average of all STRs. The taxonomic status of all species was derived using the WORMS database (obtained using the taxize library in R, Chamberlain \& Szocs, 2013). Species were further divided into animals (Kingdom Animalia) and plants/algae (Kingdoms Plantae and Chromista) for separate calculation of community thermal metrics.

Spatial patterns in Community Temperature Index on UK and European rocky shore were based on data recorded by the MarClim programme (Nova Mieszkowska, Firth, \& Bentley, 2013). Trends in CTI over time used data collected on annual visits to sites in the MarClim programme since 2001 and since 1976 in the SOTEAG (Shetland Oil Terminal Environmental Advisory Group) environmental monitoring programme around Sullom Voe (Burrows, Moore, \& James, 2002; Hiscock, 1981). 
Rocky intertidal surveys for MarClim followed a common protocol, recording the abundance of conspicuous species in the parts of the habitat where they were usually found (Burrows et al., 2008; N. Mieszkowska, Leaper, et al., 2006). Counts and assessments of cover in randomly placed quadrats, along with timed searches for species so infrequent that they were not likely to appear in quadrats, were used to return the category of abundance for that species. Survey effort was controlled to complete the search for checklist species within $1-2 \mathrm{~h}$, and over a shoreline extent of $50-200 \mathrm{~m}$. The seven abundance categories ranged from "not seen" despite searching during the low-tide survey period to "superabundant". Ranks of these categories were used in subsequent analysis ( 0 , absent; 1, Rare; 2, Occasional; 3 , Frequent; 4, Common; 5, Abundant; 6, Super abundant; 7, Extremely abundant). Survey locations were recorded using handheld GPS. 2489 MarClim surveys had been completed to the end of 2018. Most locations were along the coasts of the UK and Ireland, with some on the coast of continental Europe. Survey effort was more intensive during the first phase of the MarClim project (2002-2005), with subsequent surveys extending the spatial coverage of the dataset or examining longer-term changes: 61 sites around the UK coastline have been surveyed approximately annually from 2004 to 2018 (>10 visits in 14 years). Rocky shores in Shetland were surveyed annually under the SOTEAG programme from 1976 to 2018. Fixed transects ran perpendicular to the shoreline from mean low water of spring tides to above mean high water of spring tides. Abundance (on the same categorical scales as MarClim) was estimated for each species in $3 \times 0.1 \mathrm{~m}$ horizontal strips on either side of the transect line at five shore levels, using small quadrats to aid estimation. Average species abundance category rank per transect per year across the five shore levels was used to calculate abundance-weighted CTI, CTDiv and CTR, approximately equivalent to a logarithmic or logit data transformation of abundance.

Spatial patterns in community thermal metrics were visualised by spatial averaging of values into $0.5^{\circ}$ latitude-longitude cells, $(\mathrm{c} 50 \mathrm{x} 30 \mathrm{~km})$. Site-specific community thermal metrics were compared with an index of local wave exposure, the summed wave fetch (distance to the nearest point of land in 32 directional sectors (Burrows, 2012). Relationships of site-average thermal metrics with temperature and wave exposure were modelled using generalised linear models with a spherical spatial correlation structure, with goodness-of-fit expressed as equivalent $R^{2}$ determined from correlation between observed and predicted values. 
Temporal trends in community thermal metrics calculated from annual site surveys were compared with local trends in sea surface temperature (SST). Change in SST was expressed as annual means for $0.25^{\circ}$ latitude-longitude grid cells extracted from the NOAA OISST HR V2 dataset (Reynolds, Rayner, Smith, Stokes, \& Wang, 2002). Trends in CTI were estimated using simple linear regression of values at each site in the core set of annually surveyed sites. Annual CTI changes were compared with changes in local SST using linear mixed models applied to site-specific CTI and SST, with an AR1 temporally auto-correlated error term (Pinheiro, Bates, DebRoy, Sarkar, \& R Core Team, 2018). Sites were included in models as a random factor; either as a random intercept or random slope according to whichever model gave the lower AIC value. Trends in species abundance over time and versus sea surface temperature were evaluated using simple linear regression on annual average abundance values. Slopes of abundance versus time and temperature in southwest Britain and Shetland were compared with species thermal affinities (STIs) to assess the expectation that warm-affinity species (STI>local temperature) would increase with warming (or decrease with cooling) and cold-affinity species would decrease with warming (and increase with cooling).

\section{Results}

Spatial patterns in community thermal metrics

The primary measure of community-level response to temperature is the average thermal affinity across species (Community Temperature Index, CTI). CTI patterns across latitudinal and regional temperature gradients can indicate how such communities may respond to changing temperatures over time. CTI values aggregated into $0.5^{\circ}$ latitudelongitude areas (Figs 1-2) increased with sea surface temperature, but CTI for animal species (aCTI, Fig. 2a) changed more rapidly with sea surface temperature than did CTI for plants and algae (mCTI, Fig. 2b). The potential microclimatic effect of increased cover of macroalgae in wave-sheltered areas was supported by a positive relationship between wave exposure and CTI for communities composed of animal species (Table 1, Fig. 3a). No such trend in CTI was seen for communities composed of plants and algae (Fig. 3b).

High variability in thermal affinities among species (Community Thermal Diversity, CTDiv; the abundance-weighted standard deviation of species thermal midpoints) can show where change in community composition in relation to temperature is expected to be greater. CTDiv was generally higher for communities of animal species than for plants and algae 
(Fig. S1). CTDiv did not change with temperature for animal communities but did increase with temperature for plant-algae communities (Fig. S1, Table S3). CTDiv was higher on more wave-exposed shores than wave-sheltered shores for both animal and plant-algae communities (Fig. S1b, Table S3), increasing by $0.3^{\circ} \mathrm{C}$ for each order of magnitude increase in summed wave fetch.

Larger average species thermal range (Community Thermal Range, CTR) was expected to indicate reduced response of community composition to temperature, with broadranged species expected to change in abundance at a reduced rate with distance across their geographical ranges. CTR was similar for plant and animal communities, but declined with temperature in animal communities (Fig. S1c). CTR also declined with wave exposure (Table S3) for plant and algal species, but not animals, thus rocky intertidal communities in waveexposed places tended to be composed of narrower-ranged species of algae than those in wave shelter (Fig. S1f).

Community Thermal Bias (CTI less local temperature) is a likely indicator of the general vulnerability of species to temperature change: negative values showing a preponderance of cold-affinity species likely to decline with warming (Stuart-Smith et al., 2015) and positive values indicating communities composed of warm-water species likely to increase in abundance with warming. Animal communities had generally positive Community Thermal Bias, being above the dashed line of equality of CTI and SST in Fig 2a. Animal species in rocky shore communities generally had global distributions that were centred in waters $1-2^{\circ} \mathrm{C}$ warmer than the sites surveyed. In contrast, communities of plants and algae had strongly negative thermal bias, with species having STIs that were $1-3^{\circ} \mathrm{C}$ colder than local temperatures (Fig. 2b).

Species richness in surveys showed considerable geographical variation alongside patterns of changing thermal composition of communities (Fig. S2). The total number of species present in a single site survey increased by 0.9 per ${ }^{\circ} \mathrm{C}$ increase in average annual sea surface temperature (Table 1), mostly due to an increase in animal species richness, while species richness of plants and algae declined with SST. Wave-exposed locations tended to have greater numbers of species present in surveys $(+2.3$ species per order of magnitude increase in summed wave fetch, Table 1), an increase in both animal species richness $(+3.2$ per order of magnitude, Fig S2c) and plant and algal species richness $(+1.1$ species per order of magnitude, Fig S2d). 


\section{Temporal trends in community thermal metrics}

The two regional community time-series both showed changes in CTI over time (Fig. 4, Table 2, Tables S4 and S5 for site-specific trends). CTI declined by $0.5^{\circ} \mathrm{C}$ in southwest England and Wales over 17 years from 2002 to 2018, with most of the decrease in the first 10 years. CTI increased in Shetland by a similar amount, steadily rising from 1980 onwards after an initial decline post 1976. Trends in all-species CTI broadly followed the patterns of regional temperature changes in each case. In Shetland, the initial drop in CTI in the late 1970s matched a similar fall in annual SST, while the steady increase post 1980 followed the general upward SST trend. Animal-species CTI showed the same pattern as the all-species CTI in Shetland, with annual CTI values being related to annual SST anomalies (Table 2, $\mathrm{p}<0.05)$. Plant and algae-based CTI in Shetland declined significantly over the same period (Fig. 4, mCTI), and was not related to local SST. Declines in CTI for all species and separately for animals and plants and algae in southwest Britain were relatively steady over the 17-year period but were not significantly related to local SST anomalies (Table 2, sitespecific CTI values versus SST anomalies: random-intercepts linear mixed model).

In southwest Britain, trends in species abundance over time (as annual averages across all sites) were strongly related to individual species thermal midpoints. During the period from 2002 to 2018, cold-affinity species of both animals and algae increased in abundance at the 60 most frequently surveyed sites ( $>=10$ times) while warm-affinity species both increased and decreased (Fig. 5a, Fig. S3). Rate of change in species abundance over time was significantly negatively related to STI $(p=0.005)$. When compared to annual changes in average sea surface temperature, average annual abundance of cold water species increased with cooling (an increase in abundance divided by a decrease in SST, Fig. 5c, Fig. S3), while warm-affinity species showed a positive rate of change in abundance relative to temperature change (slope of linear regression, $p=0.001$ ). In Shetland (Fig. 5b, 5d, Fig. S4), the pattern was less consistent, with some cold-affinity species declining (Littorina saxatilis) during warming, while others increased (Semibalanus balanoides). There were fewer warmaffinity species in the community in Shetland than in southwest Britain, and many species considered as cold-affinity species in southwest Britain (Fucus vesiculosus, Fucus spiralis) were closer to their thermal midpoint STI in Shetland. The relationships of species trends over time and with SST change with thermal affinity were not significant (though some species exerted considerable leverage on the regression slope, notably Semibalanus balanoides). 
Changes in CTI reflected changes in species abundance in the two regions. The pattern of changes in species abundance in southwest Britain relative to their thermal affinities (STIs) produced CTI changes that were consistent with a shift towards a community dominated by cold-affinity species: CTI for animal species and CTI for plants and algae decreased from 2002 to 2018. The reduced response of CTI to temperature change in Shetland was associated with an inconsistent pattern of abundance change among species. Plants and algae in Shetland had a much smaller spread of STIs $\left(0.93^{\circ} \mathrm{C}\right.$, Table S6) than in southwest Britain $\left(2.48^{\circ} \mathrm{C}\right)$, while animals in Shetland $\left(2.38^{\circ} \mathrm{C}\right)$ were also less thermally diverse than in southwest Britain $\left(4.63^{\circ} \mathrm{C}\right)$. Thermal ranges were similar in both regions.

\section{Discussion}

Implications of spatial patterns in community thermal diversity and range for community sensitivity to climate change

Patterns of community thermal metrics across regions and taxonomic groups allow evaluation of general predictions of the sensitivity of community thermal composition to temperature change. Negative thermal bias, where the community is dominated by coldaffinity species and potentially vulnerable to the effects of warming (Stuart-Smith et al., 2015), was seen for communities of macroalgae across most of the UK, increasing from eastern Scotland and northeast England towards southwest Britain and Ireland (Fig. 2b). This suggests potentially greater negative effects of climate warming on intertidal macroalgae in the southwest of the UK. Changes in abundance of large brown algae in the UK over recent times may match this expectation, with declines in abundance with warming in the southern half of the UK and no changes in central and northern regions (Yesson, Bush, Davies, Maggs, $\&$ Brodie, 2015, pp., partly using data from this study). Trends in abundance of macroalgae in southwest Britain since 2002 show the opposite trend, with macroalgae increasing during a period of stasis or slight cooling, but remain consistent with the general expectation of "thermophilization" during warming and its opposite during cooling. The pattern of increase in macroalgae in Shetland since 1976 was not consistent with this idea, with a decline in macroalgae CTI despite the marked warming suggesting other causes for the increase in coldaffinity fucoids. Communities of intertidal animals, by contrast, have mostly positive thermal bias across the study region (Fig. 2a), suggesting that intertidal animals may benefit from the effects of warming since, on average, they have distributions centred in warmer areas. Warmaffinity animal species declined with cooling in the southwest, but the main contribution to 
changing CTI in Shetland was the decline in cold-affinity animals with warming.

Communities with more widely varying species thermal affinities (lower CTDiv) have been predicted to have CTI values that are more sensitive to change in environmental temperature (Burrows et al., 2019), since they are more likely to show change in species relative abundance. Here, animal communities are markedly more thermally diverse than plant communities in both regions with time series, and in both regions CTI for animal communities responded more to temperature increase than CTI for plant communities. Thus, communities in southwest England and Wales that are comprised of a mix of lusitanian and boreal species are more likely to show changes: biogeographic transition zones may be "hotspots" for observing climate-related shifts in community composition. Among sites in southwest Britain, trends were not related to relatively small differences in CTDiv and CTR. Greater change in community composition was expected at wave-exposed sites, since wavesheltered sites have been considered as stable and characterised by long-lived species such as Ascophyllum nodosum (Lewis, 1976). A slower or delayed response to temperature, associated with dominance by longer-lived species is suggested by the greater temporal autocorrelation of the Shetland CTI time series (Table 2).

\section{CTI response to temperature change}

The period of stable and slight cooling of sea temperatures in southwest Britain followed a period of more positive trend in temperatures the mid-1980s to 2000 (Fig. S3), during which much of the change in distribution of species since the 1960s reported at the start of the MarClim programme occurred (Herbert et al., 2003; N. Mieszkowska, Sugden, Firth, \& Hawkins, 2014; Simkanin et al., 2005). Despite the weak response to annual changes in average annual sea surface temperature, compositional changes shown by CTI were broadly in line with the longer-term trend in temperature in both southwest Britain and Shetland. Species may be responding to other aspects of temperature change, and these responses are taxon-specific. Cold-affinity species may proliferate, for example, for reasons other than temperature such as locally enhanced food supply for suspension feeders (Burrows, 2012), or due to indirect effects including changes in trophic interactions (Russell et al., 2013). The spatial pattern of CTI for animals is better aligned to the east-west gradient of winter temperatures across the UK and Ireland, while CTI for plants better matches the north-south gradient of summer temperatures, suggesting the limiting processes may occur in different seasons for the two groups. Seawater temperatures are more important than air 
temperatures at setting geographical limits for intertidal limpets (Seabra, Wethey, Santos, Gomes, \& Lima, 2016) but air temperatures may have greater effects on macroalgae, for which desiccation and osmotic stress may be more important (Davison \& Pearson, 1996). In Portugal ranges of cold-affinity algae expanded towards warmer water despite apparent warming (Lima, Ribeiro, Queiroz, Hawkins, \& Santos, 2007), potentially due to the modification of inshore temperatures by upwelling. In UK regional seas, cold-affinity fucoids showed damage during hot summers due to tide-out stress particularly high on the shore (2018, personal observations, and 1983/84, Hawkins \& Hartnoll, 1985). Contrary range responses in macroalgae suggest that other species traits may be shared among species with similar thermal affinities, generating compositional changes that result in CTI change (Bowler et al., 2017). Intertidal macroalgae may be sensitive to changes in coastal light attenuation, with reduced abundance in areas of increased coastal phytoplankton around the UK (Burrows et al., 2008). Phytoplankton increased over the region since the early 1970s (Reid, Holliday, \& Smyth, 2001), making reduced light an unlikely cause.

\section{Interactions as an influence on community composition response to warming}

In an analogous way to forest vegetation (De Frenne et al., 2013), loss of canopy may exacerbate / accelerate community change on temperate rocky shores, since canopies confer shelter. Patterns of CTI for animals across wave exposure suggest facilitation of cold-affinity animal species (e.g. Semibalanus) by canopy macroalgae (Bertness \& Leonard, 1997)(e.g. Fucus vesiculosus) on wave-sheltered shores, particularly towards range limits (and potentially higher on the shore). While sweeping by macroalgae may negatively affect some species under seaweed canopies in wave exposed places (Hawkins, 1983), seaweed canopies may protect organisms living on the rock surface from the direct heating effects of sunlight and from desiccation during tide-out periods, allowing cold-affinity species to thrive at higher average temperatures than otherwise would be possible. In-situ data loggers show that temperatures under algal canopies are up to $5^{\circ} \mathrm{C}$ lower than on exposed rock (Moore et al., 2007; Pocklington et al., 2018). Thus decline and loss of macroalgae through warming, made more likely by negative thermal bias of macroalgal communities across the UK, may accelerate change in animal communities towards warm-affinity species as the protective canopy effect is removed. Experimental evidence suggests that lost structural canopies may take many years to return (Ascophyllum nodosum, Jenkins, Norton, \& Hawkins, 2004; Petraitis \& Dudgeon, 1999). 
For strongly competing species such as barnacles, decline of a cold-affinity competitive dominant (Semibalanus balanoides) during warming can increase warm-affinity competitively inferior species (Chthamalus montagui, Poloczanska, Hawkins, Southward, \& Burrows, 2008; Wethey, 1984). Other species interactions, such as predation, may also modify climatic abundance responses, though no species pairs immediately emerge from this analysis: rates of change in abundance in relation to temperature and over time more closely follow their STIs than the changes in interacting species. Species interactions may only act locally to modify abundance patterns set at larger geographical scales. Cold-affinity macroalgae may counter-intuitively increase during warming (Lima et al., 2007) if their more susceptible cold-affinity grazers also decline, causing a reduction in grazing pressure (Coleman et al., 2006; Jenkins et al., 2005). Likewise, removal of intertidal canopy may promote the expansion of warm-affinity species (Hawkins \& Harkin, 1985).

\section{Physical microclimate as a further modifier of community response}

Physically induced spatial heterogeneity in temperatures (during emersion) on intertidal shores, with crevices, steep rock faces and boulders, may also offer local microclimates that buffer the effects of warming (Helmuth et al., 2006), where increase in temperature may reduce the amount of suitably cool habitat for cold-affinity species (Denny, Dowd, Bilir, \& Mach, 2011). Intertidal shores offer vertical temperature gradients too, with some warm-affinity species increasingly restricted to warmer, higher levels towards their cold range boundaries (Crisp, Southward, \& Southward, 1981). Proximity of areas of lower temperatures may reduce the velocity of climate change in an area and thereby the associated climatic debt (Gaüzère, Princé, \& Devictor, 2017): changes in temperature are easily accommodated by small-scale shifts in distributions (disappearance from open rock/high shore). Most of these arguments apply to conditions in the intertidal during exposure to the air; those species limited by in-affinity temperatures have no easy escape. Small-scale oceanographic features such as tidal mixing fronts (Pingree \& Griffiths, 1978) or local upwelling (Menge \& Menge, 2013) may contribute to local-scale variation in community composition among survey sites for such species.

This article is protected by copyright. All rights reserved 


\section{Broader implications}

Our study shows that community composition on rocky shores, as average species thermal affinity, does track changes in coastal sea temperature over time, especially over longer periods, during periods of both warming and cooling. Much climate-related change is occurring beside shifting species' range margins, with likely effects of changes in population abundances and relative dominance of species on the functioning of ecosystems, including the structure of marine food webs (Serpetti et al., 2017). These large spatial patterns and long-term changes in communities are consistent with the expectation that climate-driven changes in abundance are related to the thermal affinity of the constituent species compared with local temperatures, evident over long-term changes in shelf fishes (Morley, Batt, \& Pinsky, 2017; Simpson et al., 2011), but also in species responses to heatwaves (Smale et al., 2019). Combined with a greater integration with understanding of in situ species-level physiological response to temperature (Sinclair et al., 2016), this approach offers the prospect of strong predictive power as to the direction of community compositional change in relation to climate in response to anthropogenic warming.

\section{Acknowledgements}

We would like to thank the field workers of the MarClim project consortium for collection of data, and the funding consortium in the UK and Ireland. We also thank SVA Ltd (Sullom Voe Association Limited) and SOTEAG (Shetland Oil Terminal Environmental Advisory Group) for funding and overall management of the Sullom Voe long-term rocky shore transect annual monitoring programme (1976-present), and the field staff and sub-contractors of ASML (Aquatic Survey \& Monitoring Ltd.), BMT CORDAH Ltd. and the FSC OPRU (Oil Pollution Research Unit).

\section{ORCID}

Michael T. Burrows https://orcid.org/0000-0003-4620-5899

Stephen J. Hawkins https://orcid.org/0000-0003-1756-9255

J. Jon Moore https://orcid.org/0000-0001-5592-3214

Leoni Adams N/A

This article is protected by copyright. All rights reserved 
Heather Sugden https://orcid.org/0000-0001-8882-3009

Louise Firth https://orcid.org/0000-0002-6620-8512

Nova Mieszkowska https://orcid.org/0000-0002-9570-7759

\section{Data availability}

The data that support the findings of this study are available from The Archive for Marine Species and Habitats Data (DASSH) at https://www.dassh.ac.uk/ and from the Shetland Oil Terminal Environmental Advisory Group (SOTEAG) at https://www.soteag.org.uk/.

\section{References}

Bates, A. E., Bird, T. J., Stuart-Smith, R. D., Wernberg, T., Sunday, J. M., Barrett, N. S., . . . others. (2015). Distinguishing geographical range shifts from artefacts of detectability and sampling effort. Diversity and Distributions, 21(1), 13-22. doi:10.1111/ddi.12263

Bertness, M. D., \& Leonard, G. H. (1997). The role of positive interactions in communities: lessons from intertidal habitats. Ecology, 78(7), 1976-1989. doi:10.1890/00129658(1997)078[1976:TROPII]2.0.CO;2

Bowler, D. E., Hof, C., Haase, P., Kröncke, I., Schweiger, O., Adrian, R., . . BöhningGaese, K. (2017). Cross-realm assessment of climate change impacts on species' abundance trends. Nature Ecology \& Evolution, 1(3), 0067. doi:10.1038/s41559-0160067

Breeman, A. (1988). Relative importance of temperature and other factors in determining geographic boundaries of seaweeds: experimental and phenological evidence. Helgoländer Meeresuntersuchungen, 42(2), 199. doi:10.1007/BF02366043

Burrows, M. T. (2012). Influences of wave fetch, tidal flow and ocean colour on subtidal rocky communities. Marine Ecology Progress Series, 445, 193-207. doi:10.3354/meps09422

Burrows, M. T., Bates, A. E., Costello, M. J., Edwards, M., Edgar, G. J., Fox, C. J., . . Poloczanska, E. S. (2019). Ocean community warming responses explained by thermal affinities and temperature gradients. Nature Climate Change, 9(12), 959-963. 
doi:10.1038/s41558-019-0631-5

Burrows, M. T., Harvey, R., \& Robb, L. (2008). Wave exposure indices from digital coastlines and the prediction of rocky shore community structure. Marine Ecology Progress Series, 353, 1-12. doi:10.3354/meps07284

Burrows, M. T., Moore, J. J., \& James, B. (2002). Spatial synchrony of population changes in rocky shore communities in Shetland. Marine Ecology Progress Series, 240, 39-48. doi:DOI 10.3354/meps240039

Burrows, M. T., Schoeman, D. S., Buckley, L. B., Moore, P., Poloczanska, E. S., Brander, K. M., . . Richardson, A. J. (2011). The pace of shifting climate in marine and terrestrial ecosystems. Science, 334(6056), 652-655. doi:10.1126/science.1210288

Chamberlain, S. A., \& Szocs, E. (2013). taxize: taxonomic search and retrieval in R. F1000Res, 2, 191. doi:10.12688/f1000research.2-191.v2

Cheung, W. W. L., Watson, R., \& Pauly, D. (2013). Signature of ocean warming in global fisheries catch. Nature, 497(7449), 365-368. doi:10.1038/nature12156

Coleman, R. A., Underwood, A. J., Benedetti-Cecchi, L., Aberg, P., Arenas, F., Arrontes, J., . . Hawkins, S. J. (2006). A continental scale evaluation of the role of limpet grazing on rocky shores. Oecologia, 147(3), 556-564. doi:10.1007/s00442-005-0296-9

Crisp, D. J., \& Fischer-Piette, E. (1959). Repartition des principales espèces intercotidales de la côte atlantique française en 1954-1955. Annales de l'Institut Océanographique de Monaco, 36, 275-287.

Crisp, D. J., \& Southward, A. J. (1958). The distribution of intertidal organisms along the coasts of the English Channel. Journal of the Marine Biological Association of the United Kingdom, 37, 157-208. doi:10.1017/S0025315400014909

Crisp, D. J., Southward, A. J., \& Southward, E. C. (1981). On the distribution of the intertidal barnacles Chthamalus stellatus, Chthamalus montagui and Euraphia depressa. Journal of the Marine Biological Association of the United Kingdom, 61, 359-380. doi:10.1017/S0025315400047007

Davison, I. R., \& Pearson, G. A. (1996). Stress tolerance in intertidal seaweeds. Journal of Phycology, 32(2), 197-211. doi:10.1111/j.0022-3646.1996.00197.x

De Frenne, P., Rodriguez-Sanchez, F., Coomes, D. A., Baeten, L., Verstraeten, G., Vellend, 
M., . . Verheyen, K. (2013). Microclimate moderates plant responses to macroclimate warming. Proceedings of the National Academy of Sciences of the United States of America, 110(46), 18561-18565. doi:10.1073/pnas.1311190110

Denny, M. W., Dowd, W. W., Bilir, L., \& Mach, K. J. (2011). Spreading the risk: Small-scale body temperature variation among intertidal organisms and its implications for species persistence. Journal of Experimental Marine Biology and Ecology, 400(1-2), 175-190. doi:10.1016/j.jembe.2011.02.006

Devictor, V., Julliard, R., Couvet, D., \& Jiguet, F. (2008). Birds are tracking climate warming, but not fast enough. Proceedings of the Royal Society of London B: Biological Sciences, 275(1652), 2743-2748. doi:10.1098/rspb.2008.0878

Devictor, V., van Swaay, C., Brereton, T., Brotons, L., Chamberlain, D., Heliola, J., . . . Jiguet, F. (2012). Differences in the climatic debts of birds and butterflies at a continental scale. Nature Climate Change, 2(2), 121-124. doi:10.1038/Nclimate1347

Firth, L. B., White, F. J., Schofield, M., Hanley, M. E., Burrows, M. T., Thompson, R. C., . . . Hawkins, S. J. (2016). Facing the future: the importance of substratum features for ecological engineering of artificial habitats in the rocky intertidal. Marine and Freshwater Research, 67(1), 131-143. doi:10.1071/Mf14163

Fischer-Piette, E. (1936). Études sur la biogéographie intercôtidale des deux rives de la Manche. Journal of the Linnaean Society (Zoology), 40, 181-272.

Flanagan, P. H., Jensen, O. P., Morley, J. W., \& Pinsky, M. L. (2019). Response of marine communities to local temperature changes. Ecography, 42(1), 214-224. doi:10.1111/ecog.03961

Gaüzère, P., Princé, K., \& Devictor, V. (2017). Where do they go? The effects of topography and habitat diversity on reducing climatic debt in birds. Global Change Biology, 23(6), 2218-2229. doi:10.1111/gcb.13500

Genner, M. J., Sims, D. W., Wearmouth, V. J., Southall, E. J., Southward, A. J., Henderson, P. A., \& Hawkins, S. J. (2004). Regional climatic warming drives long-term community changes of British marine fish. Proc Biol Sci, 271(1539), 655-661. doi:10.1098/rspb.2003.2651

Givan, O., Edelist, D., Sonin, O., \& Belmaker, J. (2018). Thermal affinity as the dominant factor changing Mediterranean fish abundances. Glob Chang Biol, 24(1), e80-e89. 
doi:10.1111/gcb.13835

Hawkins, S. J. (1983). Interactions of Patella and macroalgae with settling Semibalanus balanoides (L). Journal of Experimental Marine Biology and Ecology, 71(1), 55-72. doi:10.1016/0022-0981(83)90104-1

Hawkins, S. J., \& Harkin, E. (1985). Preliminary canopy removal experiments in algal dominated communities low on the shore and in the shallow subtidal on the Isle of Man. Botanica Marina, 28(6), 223-230. doi:10.1515/botm.1985.28.6.223

Hawkins, S. J., \& Hartnoll, R. G. (1985). Factors determining the upper limits of intertidal canopy-forming algae. Marine Ecology Progress Series, 20(3), 265-271. doi:10.3354/meps020265

Hawkins, S. J., Sugden, H. E., Mieszkowska, N., Moore, P. J., Poloczanska, E., Leaper, R., . . . Burrows, M. T. (2009). Consequences of climate-driven biodiversity changes for ecosystem functioning of North European rocky shores. Marine Ecology Progress Series, 396, 245-259. doi:10.3354/meps08378

Helmuth, B., Broitman, B. R., Blanchette, C. A., Gilman, S., Halpin, P., Harley, C. D. G., . . . Strickland, D. (2006). Mosaic patterns of thermal stress in the rocky intertidal zone: Implications for climate change. Ecological Monographs, 76(4), 461-479. doi:10.1890/0012-9615(2006)076[0461:Mpotsi]2.0.Co;2

Herbert, R. J. H., Hawkins, S. J., Sheader, M., \& Southward, A. J. (2003). Range extension and reproduction of the barnacle Balanus perforatus in the eastern English Channel. Journal of the Marine Biological Association of the United Kingdom, 83(1), 73-82. doi:10.1017/S0025315403006829h

Hiscock, K. (1981). The rocky shore ecology of Sullom-Voe. Proceedings of the Royal Society of Edinburgh Section B-Biological Sciences, 80, 219-240. doi:10.1017/S026972700000659x

Hutchins, L. W. (1947). The bases for temperature zonation in geographical distribution. Ecological Monographs, 17(3), 325-335. doi:10.2307/1948663

Jenkins, S. R., Coleman, R. A., Della Santina, P., Hawkins, S. J., Burrows, M. T., \& Hartnoll, R. G. (2005). Regional scale differences in the determinism of grazing effects in the rocky intertidal. Marine Ecology Progress Series, 287, 77-86. doi:10.3354/meps 287077 
Jenkins, S. R., Norton, T. A., \& Hawkins, S. J. (2004). Long term effects of Ascophyllum nodosum canopy removal on mid shore community structure. Journal of the Marine Biological Association of the United Kingdom, 84(2), 327-329. doi:10.1017/S0025315404009221h

Jones, S. J., Southward, A. J., \& Wethey, D. S. (2012). Climate change and historical biogeography of the barnacle Semibalanus balanoides. Global Ecology and Biogeography, 21(7), 716-724. doi:10.1111/j.1466-8238.2011.00721.x

Lewis, J. R. (1964). The Ecology of Rocky Shores: English Universities Press London.

Lewis, J. R. (1976). Long-term ecological surveillance: practical realities in the rocky littoral. Oceanography and Marine Biology: an Annual Review, 14, 371-390.

Lima, F. P., Ribeiro, P. A., Queiroz, N., Hawkins, S. J., \& Santos, A. M. (2007). Do distributional shifts of northern and southern species of algae match the warming pattern? Global Change Biology, 13, 2592-2604. doi:10.1111/j.13652486.2007.01451.x

Loarie, S. R., Duffy, P. B., Hamilton, H., Asner, G. P., Field, C. B., \& Ackerly, D. D. (2009). The velocity of climate change. Nature, 462(7276), 1052-1055. doi:10.1038/nature08649

Maclean, I. M. D., Hopkins, J. J., Bennie, J., Lawson, C. R., \& Wilson, R. J. (2015). Microclimates buffer the responses of plant communities to climate change. Global Ecology and Biogeography, 24(11), 1340-1350. doi:10.1111/geb.12359

Menge, B. A., \& Menge, D. N. L. (2013). Dynamics of coastal meta-ecosystems: the intermittent upwelling hypothesis and a test in rocky intertidal regions. Ecological Monographs, 83(3), 283-310. doi:10.1890/12-1706.1

Mieszkowska, N., Burrows, M. T., Pannacciulli, F. G., \& Hawkins, S. J. (2014). Multidecadal signals within co-occurring intertidal barnacles Semibalanus balanoides and Chthamalus spp. linked to the Atlantic Multidecadal Oscillation. Journal of Marine Systems, 133(0), 70-76. doi:10.1016/j.jmarsys.2012.11.008

Mieszkowska, N., Firth, L., \& Bentley, M. (2013). Impacts of climate change on intertidal habitats. Marine Climate Change Impacts Partnership: Science Review, 4, 180-192.

Mieszkowska, N., Kendall, M. A., Hawkins, S. J., Leaper, R., Williamson, P., HardmanMountford, N. J., \& Southward, A. J. (2006). Changes in the range of some common 
rocky shore species in Britain - a response to climate change? Hydrobiologia, 555, 241-251. doi:10.1007/s10750-005-1120-6

Mieszkowska, N., Leaper, R., Moore, P., Kendall, M. A., Burrows, M. T., Lear, D., . . Hawkins, S. J. (2006). Marine biodiversity and climate change assessing and predicting the influence of climatic change using intertidal rocky shore biota. Scottish Natural Heritage Commissioned Report No. 202 (ROAME No. F01AA402), 1-53.

Mieszkowska, N., Sugden, H., Firth, L. B., \& Hawkins, S. J. (2014). The role of sustained observations in tracking impacts of environmental change on marine biodiversity and ecosystems. Philos Trans A Math Phys Eng Sci, 372(2025), 20130339. doi:10.1098/rsta.2013.0339

Moore, P., Hawkins, S. J., \& Thompson, R. C. (2007). Role of biological habitat amelioration in altering the relative responses of congeneric species to climate change. Marine Ecology Progress Series, 334, 11-19. doi:10.3354/meps334011

Morley, J. W., Batt, R. D., \& Pinsky, M. L. (2017). Marine assemblages respond rapidly to winter climate variability. Glob Chang Biol, 23(7), 2590-2601. doi:10.1111/gcb.13578

Petraitis, P. S., \& Dudgeon, S. R. (1999). Experimental evidence for the origin of alternative communities on rocky intertidal shores. Oikos, 84(2), 239-245. doi:10.2307/3546718

Pingree, R. D., \& Griffiths, D. K. (1978). Tidal fronts on the shelf seas around the British Isles. Journal of Geophysical Research, 83, 4615-4622. doi:10.1029/JC083iC09p04615

Pinheiro, J., Bates, D., DebRoy, S., Sarkar, D., \& R Core Team. (2018). nlme: Linear and Nonlinear Mixed Effects Models.

Pocklington, J. B., Jenkins, S. R., Bellgrove, A., Keough, M. J., O'Hara, T. D., MastersonAlgar, P. E., \& Hawkins, S. J. (2018). Disturbance alters ecosystem engineering by a canopy-forming alga. Journal of the Marine Biological Association of the United Kingdom, 98(4), 687-698. doi:10.1017/S0025315416002009

Poloczanska, E. S., Brown, C. J., Sydeman, W. J., Kiessling, W., Schoeman, D. S., Moore, P. J., . . Richardson, A. J. (2013). Global imprint of climate change on marine life. Nature Climate Change, 3(10), 919-925. doi:10.1038/Nclimate1958

Poloczanska, E. S., Hawkins, S. J., Southward, A. J., \& Burrows, M. T. (2008). Modeling the 
Response of Populations of Competing Species to Climate Change. Ecology, 89(11), 3138-3149. doi:10.1890/07-1169.1

Prince, K., \& Zuckerberg, B. (2015). Climate change in our backyards: the reshuffling of North America's winter bird communities. Glob Chang Biol, 21(2), 572-585. doi: $10.1111 / \mathrm{gcb} .12740$

Reid, P. C., Holliday, N. P., \& Smyth, T. J. (2001). Pulses in the eastern margin current and warmer water off the north west European shelf linked to North Sea ecosystem changes. Marine Ecology Progress Series, 215, 283-287. doi:10.3354/meps215283

Reynolds, R. W., Rayner, N. A., Smith, T. M., Stokes, D. C., \& Wang, W. Q. (2002). An improved in situ and satellite SST analysis for climate. Journal of Climate, 15(13), 1609-1625. doi:10.1175/1520-0442(2002)015<1609:Aiisas >2.0.Co;2

Reynolds, R. W., Smith, T. M., Liu, C., Chelton, D. B., Casey, K. S., \& Schlax, M. G. (2007). Daily high-resolution-blended analyses for sea surface temperature. Journal of Climate, 20(22), 5473-5496. doi:10.1175/2007jcli1824.1

Russell, B. D., Connell, S. D., Findlay, H. S., Tait, K., Widdicombe, S., \& Mieszkowska, N. (2013). Ocean acidification and rising temperatures may increase biofilm primary productivity but decrease grazer consumption. Philosophical Transactions of the Royal Society B-Biological Sciences, 368(1627), 20120438. doi:10.1098/rstb.2012.0438

Seabra, R., Wethey, D. S., Santos, A. M., Gomes, F., \& Lima, F. P. (2016). Equatorial range limits of an intertidal ectotherm are more linked to water than air temperature. Global Change Biology, 22(10), 3320-3331. doi:10.1111/gcb.13321

Seabra, R., Wethey, D. S., Santos, A. M., \& Lima, F. P. (2015). Understanding complex biogeographic responses to climate change. Sci Rep, 5, 12930. doi:10.1038/srep12930

Serpetti, N., Baudron, A. R., Burrows, M. T., Payne, B. L., Helaouet, P., Fernandes, P. G., \& Heymans, J. J. (2017). Impact of ocean warming on sustainable fisheries management informs the Ecosystem Approach to Fisheries. Sci Rep, 7(1), 13438. doi:10.1038/s41598-017-13220-7

Simkanin, C., Power, A., Myers, A., McGrath, D., Southward, A., Mieszkowska, N., .. . O'Riordan, R. (2005). Using historical data to detect temporal changes in the abundances of intertidal species on Irish shores. Journal of the Marine Biological 
Association of the United Kingdom, 85(6), 1329-1340.

doi:10.1017/S0025315405012506

Simpson, S. D., Jennings, S., Johnson, M. P., Blanchard, J. L., Schon, P. J., Sims, D. W., \& Genner, M. J. (2011). Continental shelf-wide response of a fish assemblage to rapid warming of the sea. Current Biology, 21(18), 1565-1570.

doi:10.1016/j.cub.2011.08.016

Sinclair, B. J., Marshall, K. E., Sewell, M. A., Levesque, D. L., Willett, C. S., Slotsbo, S., .. . Helmuth, B. S. (2016). Can we predict ectotherm responses to climate change using thermal performance curves and body temperatures? Ecology Letters, 19(11), 13721385. doi:10.1111/ele.12686

Smale, D. A., Wernberg, T., Oliver, E. C. J., Thomsen, M., Harvey, B. P., Straub, S. C., . . Moore, P. J. (2019). Marine heatwaves threaten global biodiversity and the provision of ecosystem services. Nature Climate Change, 9(4), 306-312. doi:10.1038/s41558019-0412-1

Sorte, C. J. B., Williams, S. L., \& Carlton, J. T. (2010). Marine range shifts and species introductions: comparative spread rates and community impacts. Global Ecology and Biogeography, 19(3), 303-316. doi:10.1111/j.1466-8238.2009.00519.x

Southward, A. J. (1991). Forty years of changes in species composition and population density of barnacles on a rocky shore near Plymouth. Journal of the Marine Biological Association of the UK, 71, 495-513. doi:10.1017/S002531540005311X

Southward, A. J., \& Crisp, D. J. (1954). The distribution of certain intertidal animals around the Irish coast. Proceedings of the Royal Irish Academy, 57B(B1), 1-29.

Southward, A. J., \& Crisp, D. J. (1954). Recent changes in the distribution of the intertidal barnacles Chthamalus stellatus Poli and Balanus balanoides L. in the British Isles. Journal of Animal Ecology, 23, 163-177. doi:10.2307/1665

Southward, A. J., Hawkins, S. J., \& Burrows, M. T. (1995). Seventy years' observations of changes in distribution and abundance of zooplankton and intertidal organisms in the western English Channel in relation to rising sea temperature. Journal of Thermal Biology, 20(1-2), 127-155. doi:10.1016/0306-4565(94)00043-I

Stuart-Smith, R. D., Edgar, G. J., Barrett, N. S., Kininmonth, S. J., \& Bates, A. E. (2015). Thermal biases and vulnerability to warming in the world's marine fauna. Nature, 
528(7580), 88-92. doi:10.1038/nature16144

Sunday, J. M., Bates, A. E., \& Dulvy, N. K. (2012). Thermal tolerance and the global redistribution of animals. Nature Climate Change, 2(9), 686-690. doi:10.1038/Nclimate1539

Tayleur, C. M., Devictor, V., Gauzere, P., Jonzen, N., Smith, H. G., \& Lindstrom, A. (2016). Regional variation in climate change winners and losers highlights the rapid loss of cold-dwelling species. Diversity and Distributions, 22(4), 468-480. doi:10.1111/ddi.12412

Tingley, M. W., \& Beissinger, S. R. (2009). Detecting range shifts from historical species occurrences: new perspectives on old data. Trends in Ecology \& Evolution, 24(11), 625-633. doi:10.1016/j.tree.2009.05.009

Wethey, D. S. (1984). Sun and Shade Mediate Competition in the Barnacles Chthamalus and Semibalanus - a Field Experiment. Biological Bulletin, 167(1), 176-185. doi: $10.2307 / 1541346$

Yesson, C., Bush, L. E., Davies, A. J., Maggs, C. A., \& Brodie, J. (2015). Large brown seaweeds of the British Isles: Evidence of changes in abundance over four decades. Estuarine Coastal and Shelf Science, 155, 167-175. doi:10.1016/j.ecss.2015.01.008

\section{Supporting Information}

Additional Supporting Information may be found in the online version of this article.

Table S1 Species Temperature Index (STI) values for the subset of UK rocky shore species used in CTI estimation.

Table S2 Literature sources for global distributions of selected UK rocky shore species used for Species Temperature Index estimation.

Table S3 Spatial variation in thermal community composition metrics related to siteaveraged values with local sea surface temperature and site-specific wave exposure.

Table S4 CTI trends in Shetland time series by site, 1984-2018.

Table S5 CTI trends in MarClim time series by site, 2002-2018,

Table S6 Regional average community thermal metrics at time-series sites. 
Fig. S1 Patterns in community thermal metrics across temperature and wave exposure gradients.

Fig. S2 Patterns in species richness for rocky-shore animal communities and plant-algal communities across temperature and wave exposure gradients.

Fig. S3 Changes in average abundance of predominant species in MarClim surveys across frequently sampled sites in southwest Britain from 2002 to 2018.

Fig. S4 Changes in average abundance of predominant species in SOTEAG surveys at sites around Sullom Voe in Shetland from 1976 to 2018. 


\section{Figures}

$\begin{array}{ll}\text { (a) Animal species: aCTI } & \text { (b) Algae and plant species: } \mathrm{mCTI}\end{array}$

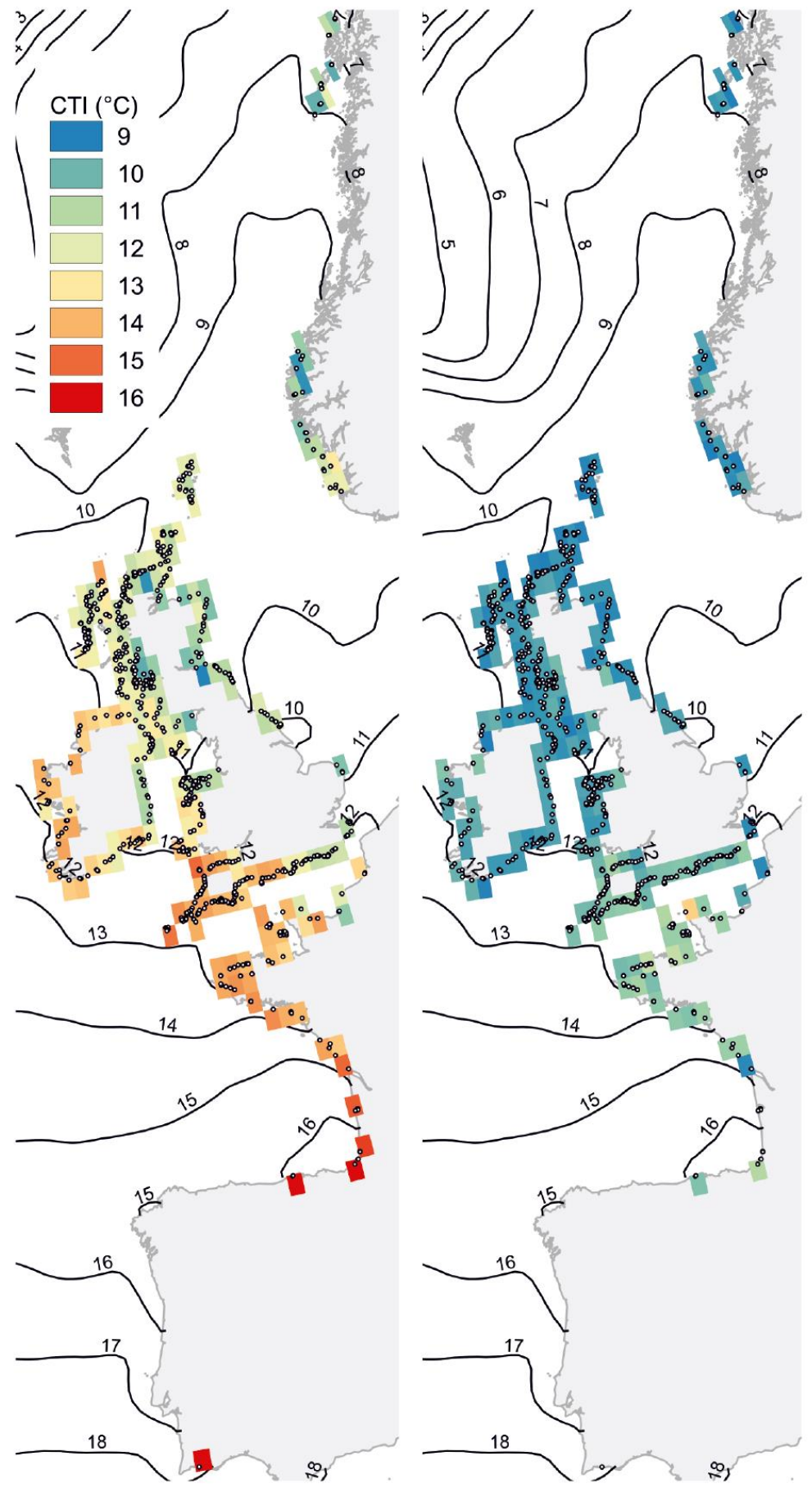

Fig. 1 Geographical patterns in CTI for (a) animals and (b) plants and algae. Community Temperature Index values are shown as averages in $0.5^{\circ}$-degree grid cells, with survey sites as open circles. Isotherms are average annual sea surface temperature at $1^{\circ} \mathrm{C}$ intervals from the NOAA OISSTv2 HR dataset. 
(a) Animal species: aCTI

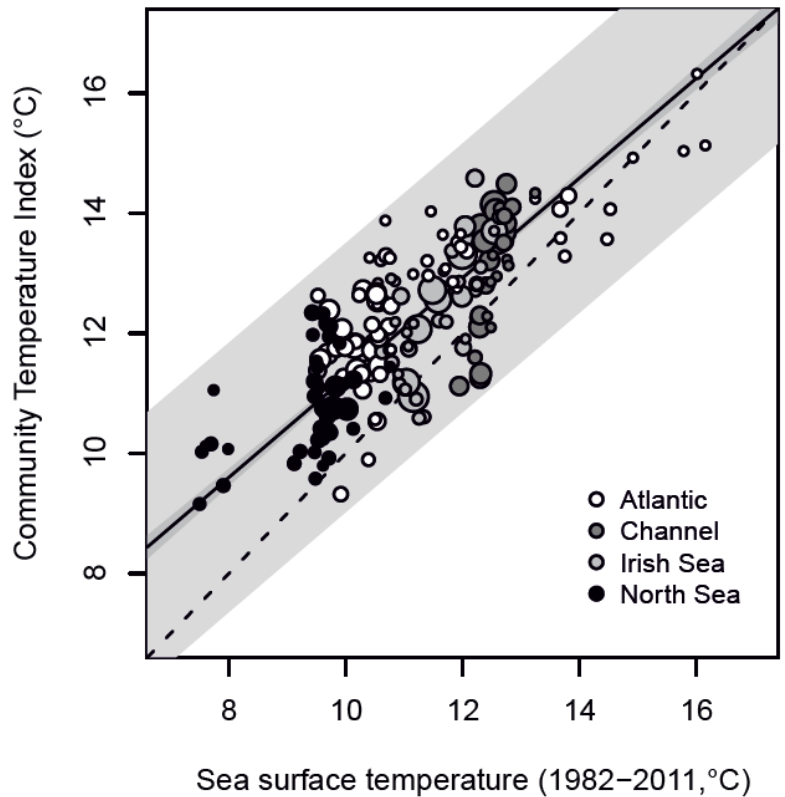

(b) Algae and plant species: $\mathrm{mCTI}$

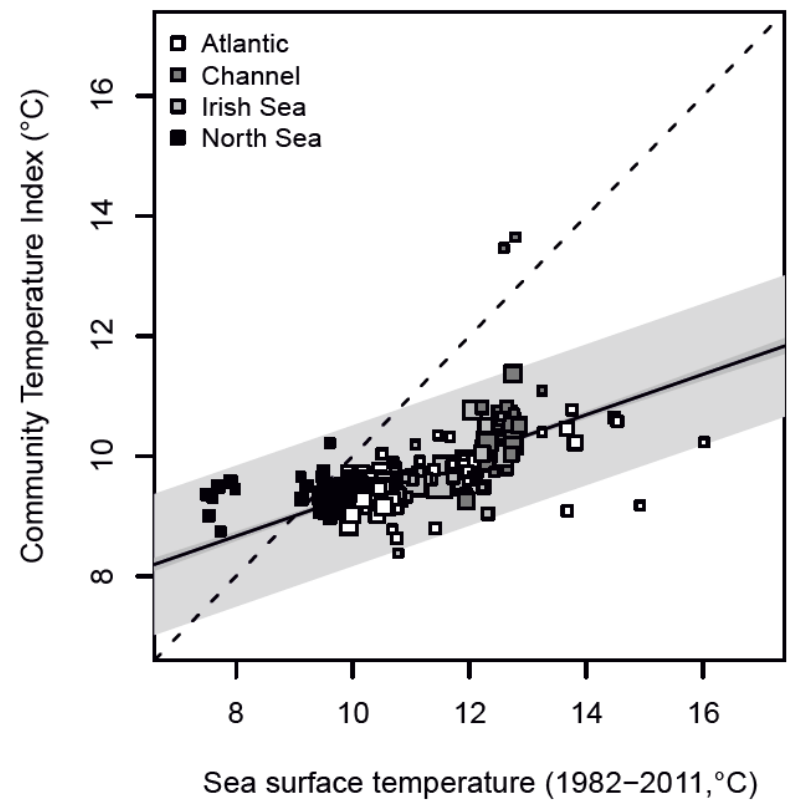

Fig. 2 Community Temperature Index versus average annual sea surface temperature. CTI for (a) animal species is more sensitive to local SST $\left(R^{2}=0.46, y=2.75(0.22)+0.85(0.02) x\right.$, standard errors in paretheses) than for (b) algal species $\left(R^{2}=0.32, y=5.94(0.12)+\right.$ $0.34(0.01) x$ ). Solid lines show regressions with 95\% confidence intervals for slopes (dark grey ribbon) and predicted values (light grey); dashed lines show 1:1. Symbols show mean CTI values for data aggregated into $0.5^{\circ}$ latitude-longitude cells with symbol size indicating the number of sites in each cell and shading denoting coastlines. 
(a) Animal species: aCTI

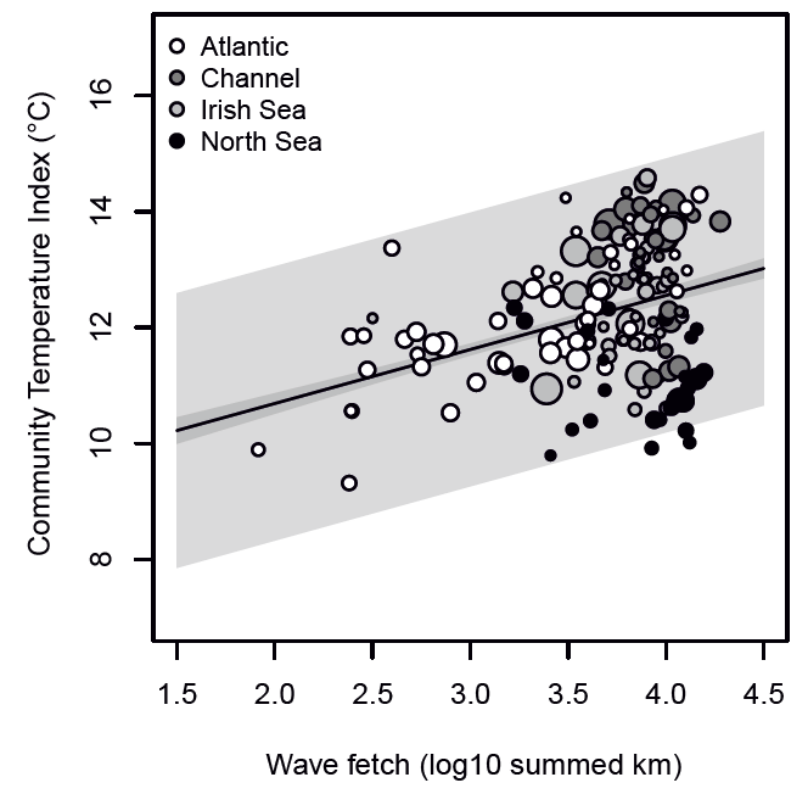

(b) Algae and plant species: $\mathrm{mCTI}$

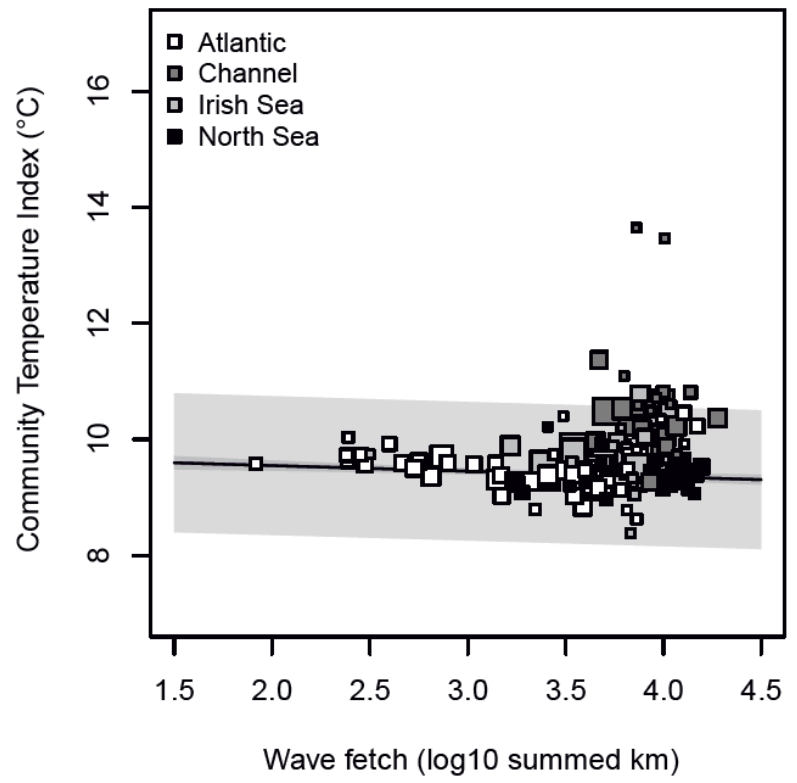

Fig. 3 (a) Animal communities in wave-sheltered conditions tend to be composed of species with cooler thermal affinities than in wave-exposed conditions $\left(R^{2}=0.36, y=9.10(0.20)+\right.$ $0.86(0.06) x+$ region terms $)$, a trend not seen in (b) algal communities $\left(R^{2}=0.26, y=\right.$ $9.65(0.10)-0.07(0.03) x+$ region terms). Solid lines show regressions with $95 \%$ confidence intervals for slopes (dark grey ribbon) and predictions (light grey ribbon) for Atlantic coastal sites. Symbols show CTI values for data aggregated into $0.5^{\circ}$ latitude-longitude cells, with size indicating the number of sites in each cell. 


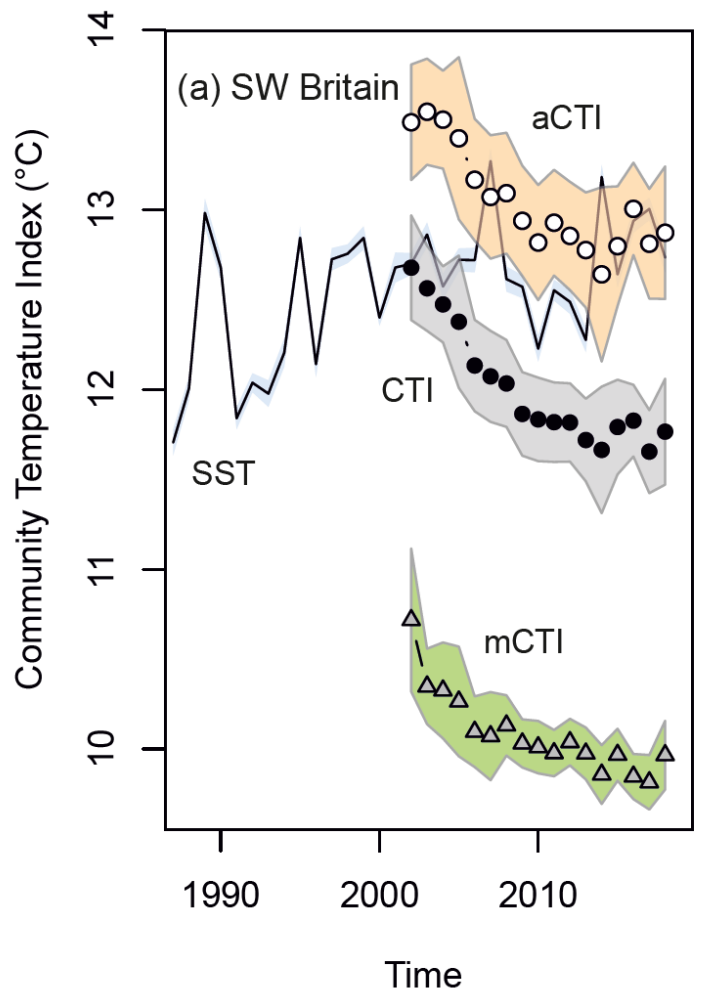

(b) Shetland

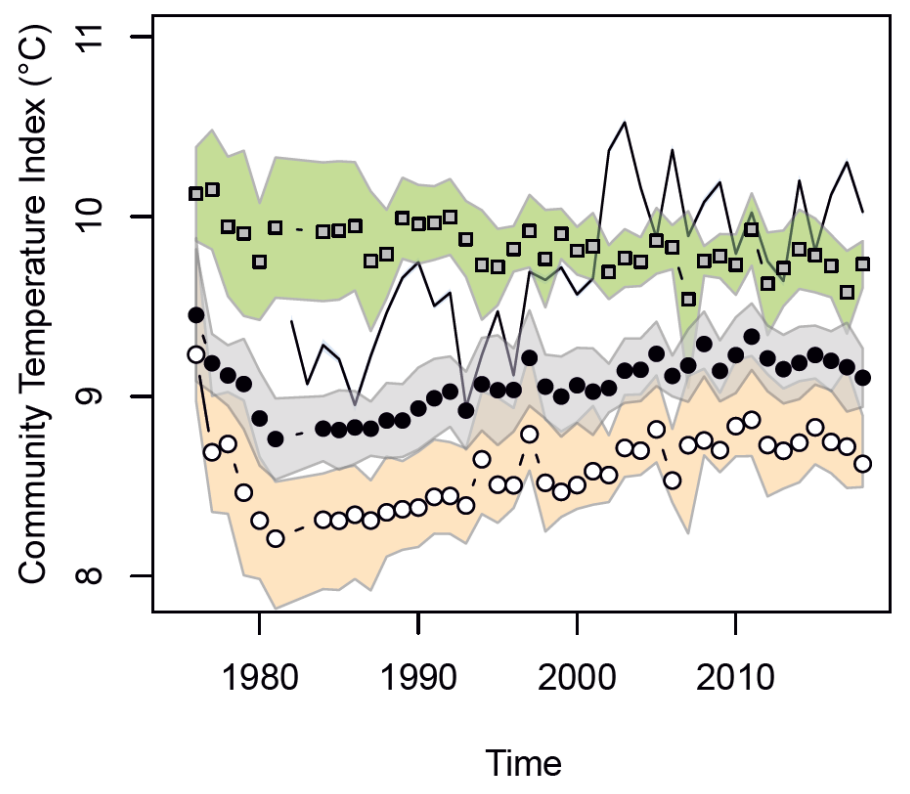

Fig. 4 Change in Community Temperature Index in (a) southwest Britain ( $\mathrm{n}=40$ sites) and (b) Shetland ( $\mathrm{n}=15$ sites) as annual means across sites for all species combined (CTI, filled circles), animal species (aCTI, open circles) and plants and algae (mCTI, shaded squares Shetland, triangles SW Britain). Regional sea surface temperatures are shown as mean annual temperatures for each region from OISST HR V2. Uncertainties are shown as 95\% confidence intervals of means (shaded ribbons) of site CTI values, and for SST as ranges of values in neighbouring grid cells . 
(a) SW Britain: Abundance change per year

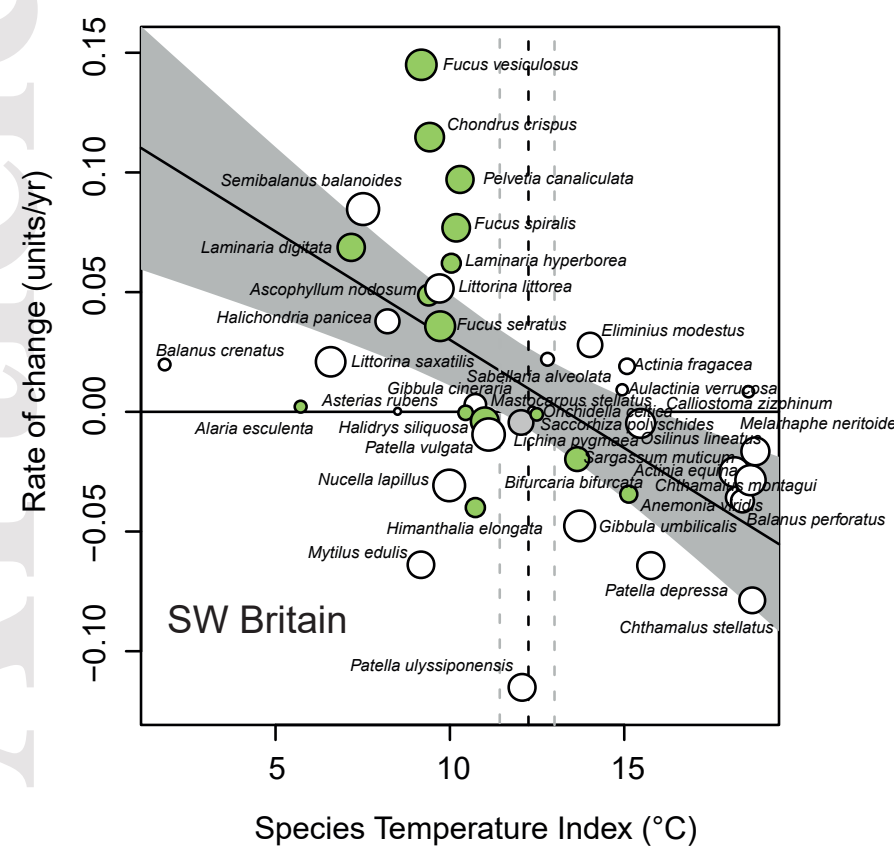

(c) SW Britain: Abundance change per ${ }^{\circ} \mathrm{C}$

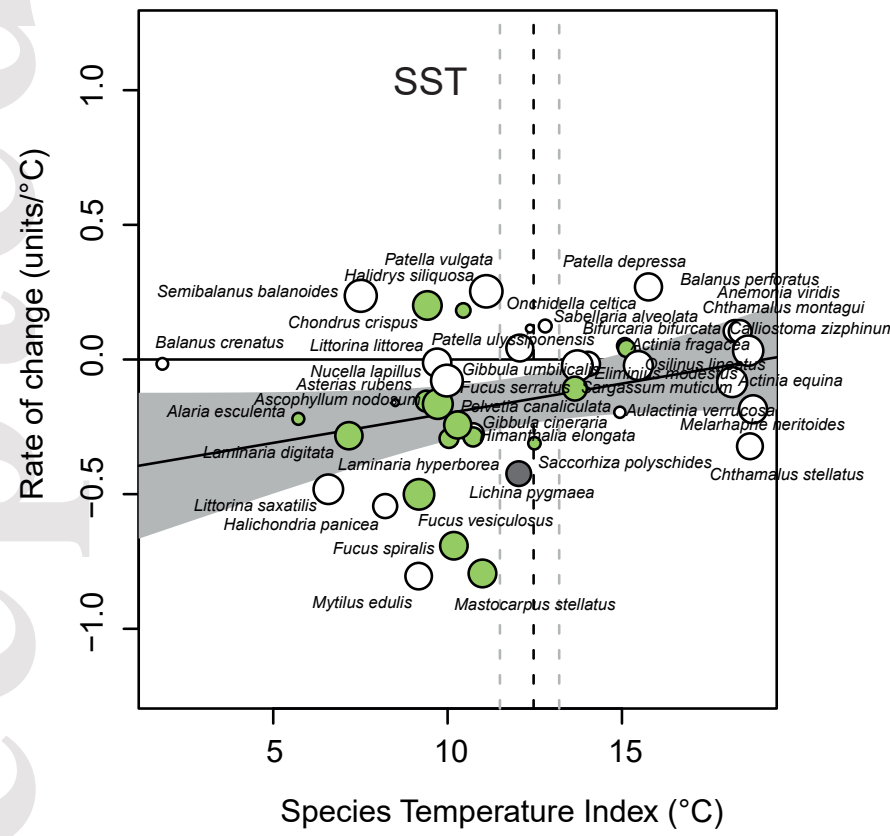

(b) Shetland: Abundance change per year

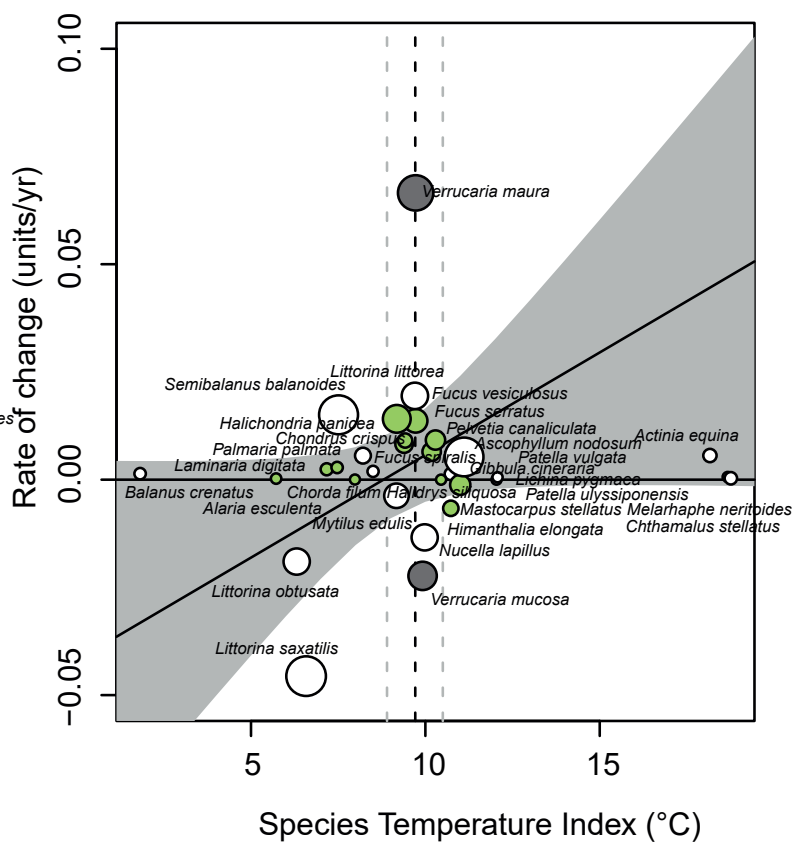

(d) Shetland: Abundance change per ${ }^{\circ} \mathrm{C}$

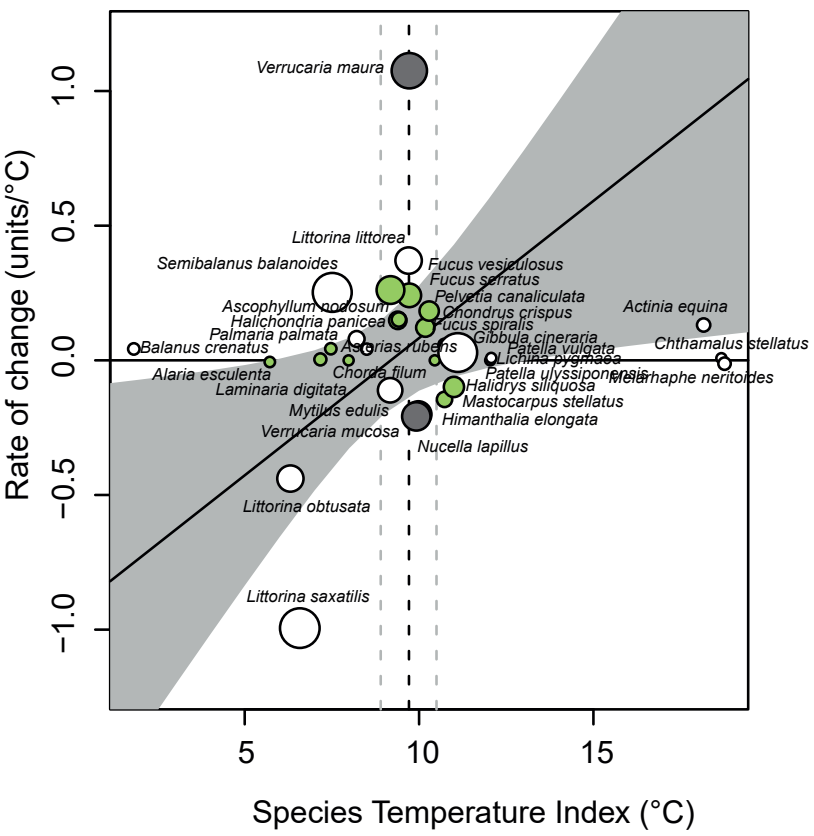


Fig. 5 Trends in species abundance in (a, c) SW Britain (2002-2018) and (b, c) Shetland (1984-2018) related to species thermal affinities (Species Temperature Index). Each point represents the regression coefficient for a single species against $(a, b)$ regional annual SST and (c, d) years. Species thermal affinities (STI) influenced trends over time in SW Britain (a, $\left.R^{2}=0.15, \mathrm{P}=0.005\right)$ and mariginally in Shetland $\left(\mathrm{b}, R^{2}=0.09, \mathrm{P}=0.06\right)$. Trends with SST in were related to STI in SW Britain $\left(\mathrm{a}, R^{2}=0.06, \mathrm{P}=0.06\right)$ and Shetland $\left(\mathrm{b}, R^{2}=0.13, \mathrm{P}=0.03\right)$. Regressions are shown by slopes and their $95 \%$ confidence levels as shaded areas. Shaded circles, plants and algae; white circles, animals; sizes of circles scaled to proportional frequency of species, used as weighting in regression. Vertical dashed lines show average (black) and range (grey) in local annual average SST. 
Table 1 Spatial variation in thermal community composition metrics related to site-averaged values with local sea surface temperature and site-specific wave exposure $\left(\log _{10}\right.$ summed wave fetch). Values are parameter estimates and t-values from generalised linear models with spherical spatial correlation structure, using site-averaged community thermal metrics as the response variable $(\mathrm{n}=912)$. All $\mathrm{p}$-values $<0.001$ except $\S$. Equivalent $R^{2}$ values shown in brackets.

\begin{tabular}{|c|c|c|c|c|c|c|c|}
\hline \multicolumn{2}{|r|}{ Estimate } & SE & $\mathbf{t}$ & & Estimate & SE & $\mathbf{t}$ \\
\hline \multicolumn{4}{|c|}{ CTI, Community Temperature Index $\left(R^{2} 0.594\right)$} & \multicolumn{2}{|c|}{ Species richness } & \multicolumn{2}{|c|}{$\left(R^{2} 0.076\right)$} \\
\hline (Intercept) & 2.96 & 0.233 & 12.72 & (Intercept) & $\$ 2.703$ & 2.266 & 1.19 \\
\hline SST & 0.681 & 0.021 & 32.87 & SST & 0.853 & 0.202 & 4.22 \\
\hline Wave fetch & 0.191 & 0.04 & 4.79 & Wave fetch & 2.305 & 0.390 & 5.91 \\
\hline \multicolumn{2}{|c|}{ aCTI, animal species } & \multicolumn{2}{|c|}{$\left(R^{2} 0.400\right)$} & \multicolumn{2}{|c|}{ Species richness: animals } & \multicolumn{2}{|c|}{$\left(R^{2} 0.222\right)$} \\
\hline (Intercept) & 3.018 & 0.379 & 7.96 & (Intercept) & -18.652 & 2.732 & -6.83 \\
\hline SST & 0.668 & 0.034 & 19.76 & SST & 2.823 & 0.242 & 11.69 \\
\hline Wave fetch & 0.512 & 0.065 & 7.87 & Wave fetch & 3.188 & 0.471 & 6.76 \\
\hline \multicolumn{4}{|c|}{ mCTI, macroalgae and plant species } & \multicolumn{4}{|c|}{ Species richness: macroalgae and plants } \\
\hline & & \multicolumn{2}{|c|}{$\left(R^{2} 0.352\right)$} & & & \multicolumn{2}{|c|}{$\left(R^{2} 0.018\right)$} \\
\hline (Intercept) & 6.123 & 0.18 & 34 & (Intercept) & 15.088 & 1.596 & 9.45 \\
\hline SST & 0.361 & 0.016 & 22.49 & SST & -0.367 & 0.142 & -2.58 \\
\hline Wave fetch & -0.127 & 0.031 & -4.09 & Wave fetch & 1.053 & 0.275 & 3.84 \\
\hline
\end{tabular}


Table 2 Linear mixed models of changes in abundance-weighted CTI over time. For comparison of changes in CTI with temperature changes (CTI vs SST) random-intercepts models were fitted using regional sea surface temperature anomaly as a fixed factor and sites as a random factor. For trends in CTI over time similar models were fitted using year as a fixed factor. Temporal autocorrelation was included as a within-sites autoregressive (AR1) term. (Shetland time series: $\mathrm{n}$ obs $=508, \mathrm{n}$ sites $=15$, duration $=41$ years, 40 years surveyed but temperature available for 35 years from 1982 onwards. SW Britain time series: $\mathrm{n}$ obs $=815, \mathrm{n}$ sites $=60$, duration $=17$ years).

\begin{tabular}{lcccccccc}
$\begin{array}{l}\text { Shetland } \\
\text { 1984-2018 }\end{array}$ & $\begin{array}{c}\text { Fixed effects } \\
\text { Estimate }\end{array}$ & SE & Estimate & SE & $t$ & $p$ & $\begin{array}{c}\text { Random effects } \\
\text { SD }\end{array}$ & $\begin{array}{c}\text { AR1 } \\
\text { (Yntercept) }\end{array}$ \\
\hline CTI vs SST & (Intercept) & \multicolumn{9}{c}{ SST anomaly } \\
CTI & 9.078 & 0.085 & 0.133 & 0.028 & 4.784 & $<0.001$ & 0.322 & 0.514 \\
aCTI & 8.606 & 0.144 & 0.168 & 0.041 & 4.061 & $<0.001$ & 0.551 & 0.419 \\
mCTI $\dagger$ & 9.802 & 0.065 & -0.059 & 0.047 & -1.236 & 0.217 & 0.238 & 0.315 \\
& & & & & & & & \\
CTI vs Year & & & Year & & & & & \\
CTI & -12.972 & 2.652 & 0.011 & 0.001 & 8.322 & $<0.001$ & 0.322 & 0.440 \\
aCTI & -17.406 & 3.762 & 0.013 & 0.002 & 6.920 & $<0.001$ & 0.550 & 0.379 \\
mCTI & 22.148 & 4.198 & -0.006 & 0.002 & -2.941 & 0.003 & 0.238 & 0.304 \\
\hline
\end{tabular}

$($ nobs $=508$, nsites $=15)$

SW Britain Fixed effects

2002-2018

Estimate SE Estimate $\mathrm{SE} \quad t \quad p$

Random effects

\begin{tabular}{lcccccccr} 
2002-2018 & Estimate & SE & Estimate & SE & $t$ & $p$ & SD & $\begin{array}{c}\text { AR1 } \\
\text { (Year) }\end{array}$ \\
\hline CTI vs SST & (Intercept) & \multicolumn{7}{c}{ SST anomaly } \\
CTI & 11.886 & 0.113 & 0.056 & 0.044 & 1.265 & 0.206 & 0.856 & 0.341 \\
aCTI & 12.900 & 0.147 & 0.113 & 0.060 & 1.892 & 0.059 & 1.118 & -0.102 \\
mCTI & 10.039 & 0.067 & -0.099 & 0.043 & -2.273 & 0.023 & 0.488 & 0.360 \\
& & & & & & & & \\
CTI vs Year & & & Year & & & & & \\
CTI & 74.172 & 7.352 & -0.031 & 0.004 & -8.472 & $<0.001$ & 0.838 & 0.241 \\
aCTI & 36.441 & 9.319 & -0.012 & 0.005 & -2.523 & 0.012 & 1.107 & 0.153 \\
mCTI & 63.449 & 7.534 & -0.027 & 0.004 & -7.093 & $<0.001$ & 0.481 & 0.265 \\
\hline
\end{tabular}

$($ nobs $=815$, nsites $=60)$ 